\title{
WHY THE LITERARY INTERPRETATION OF A TALE IS NOT POPULAR?
}

\author{
LITTLE RED RIDING HOOD
}

\author{
Bronislava Kerbelyté
}

\begin{abstract}
Throughout times, folkloristics has focused on the relationship between the oral tradition and the printed texts of folk tales. Contemporary performers sometimes openly admit that they have read a tale in a book. Some literary tales that are well known by the community are very rarely narrated, such, for example, is Little Red Riding Hood by Charles Perrault. The text was translated into Lithuanian in the first half of the 20th century. Although profusely studied, folklore collectors have not recorded the tale in oral tradition because of available literary sources and also probably owing to its rarity in oral lore. The structure of Perrault's text is different from that of traditional folk tales. This article attempts to determine the tale type under which the tale has been classified, and describe the main plots from Perrault's text and the structures of each of these plots. It appears that Perrault has substantially transformed the folk tale, and on the basis of the tales recorded from oral tradition, an attempt will be made to reconstruct the tale heard by Perrault.
\end{abstract}

Key words: Lithuanian folklore, printed folk tales, oral lore, tale types, Little Red Riding Hood

One of the research topics in folkloristics has been the relationship between the oral tradition and the printed texts of folk tales, or their renditions by writers. In the past centuries the influence of books on oral storytelling has been noted. Lithuanian storytellers have been interested in books of folk tales since the end of the 19th century when the oral tradition was of great vitality. Contemporary performers sometimes openly admit that they have read the tale in a book and even show it to folklore collectors. Some performers borrow fragments or various details from printed translations of folk tales of other nations. Some literary tales that are well known by the community are very rarely narrated. One of such tales is Little Red Riding Hood by Charles Perrault.

The text mentioned above was translated into Lithuanian in the first half of the 20th century (Perrault 1923), and was reprinted several times in popular books and one children's tale book (Perrault 1948, 1985, 1991, 1997). The plot 
of this text has been popularised by theatre, cinema, and TV. Among the more than 85 thousand systematised variants of Lithuanian folk narratives, only 12 are classified under type AT 333; 6 of them are very close to the Ch. Perrault's text and 6 are different in detail and plot. The variants similar to the literary text were recorded during the last decades of the 20th century. One of them was recorded from a little girl and 3 variants were recorded by schoolchildren (performers are unidentified). Only one similar Belarusian variant is known among the systematised printed variants of the tales of the East Slavonians. This tale is not popular in Finland. ${ }^{1}$

The phenomenon may be explained by the fact that folklore collectors have not recorded the tale because they know its literary source. Some professional folklorists (A. Nikiforov, N. Onchukov), however, have recorded all tales performed by adult storytellers and children. During the more than 40 years of my fieldwork, I have recorded many tales connected with books and only one variant of Little Red Riding Hood, narrated by a little girl. The facts show that the other reason why the tale has not been recorded may be its rarity in oral lore.

A lot of folklorists have investigated this tale. The most popular conclusion is that children are cautioned by the tale that wolves are dangerous animals. My aim here is not to remind the conceptions at this point and I would rather draw attention only to the description of the tale type under which Little Red Riding Hood is classified.

The text of Ch. Perrault forms the descriptive context of tale type ATU 333 in The Types of International Folktales by H.-J. Uther (2004). Uther adds several motifs from other variants. (The wolf puts grandmother's blood in a glass and her flesh in a pot. The girl has to drink the blood and eat the flesh.)

Uther classifies texts with similar characters (girl, wolf, and the girl's grandmother or mother), but different plots, under the same type. The part of the type description is as follows:

In some variants Red Riding Hood arrives at grandmother's house before the wolf. The wolf climbs on the roof to wait until Red Riding Hood leaves. The grandmother, who had been making sausages, asks Red Riding Hood to pour the broth into a big trough in front of the house. Enticed by the smell, the wolf falls from the roof and drowns in the trough.

Uther also classifies several Italian variants under the same type:

An ogre (witch, wolf) is angry with the girl Catarinella and wants to devour her. He enters the girl's house pretending he is her mother (Uther 2004: 224). 
Such description raises doubts about whether the tale of $\mathrm{Ch}$. Perrault is clear for the classifier. In order to show the peculiarities of the text, the analysis of its structure has been carried out. In the following, the main plots from $\mathrm{Ch}$. Perrault's text and the structures of each of them will be described.

The protagonist of the first, third, and fourth elementary plots is Red Riding Hood. The protagonist of the second elementary plot is the girl's grandmother. The protagonist of the fifth variant is a hunter. The wolf is the antagonist in all the elementary plots.

1. The initial situation: Mother sews a red cap for her daughter and sends her to visit grandmother who lives in the forest.

The act of inducement / act of command: The mother tells the daughter not to turn from the path and not to speak to anyone.

The act of the hero: The girl turns from the path. She meets a wolf. She speaks with the wolf and tells him she is going to visit her grandmother. The wolf hurries to the grandmother's house.

The result: The wolf knows the aim of the girl's journey.

2. The initial situation: The wolf knows that the girl goes to visit her grandmother.

The act of the hero: The wolf tells the grandmother that her granddaughter has arrived. The grandmother opens the door. The wolf enters and devours the grandmother.

The result: The grandmother is in the wolf's stomach.

3. The initial situation: The grandmother is in the wolf's stomach.

The act of the hero: The wolf puts on grandmother's clothes, lies down in her bed and tells the granddaughter to enter. The girl enters the house.

The result: The girl is close to the wolf pretending to be her grandmother.

4. The initial situation: The girl and the wolf are alone in the house. The wolf pretends he is the girl's grandmother.

The act of the hero: The girl asks why the grandmother's eyes, ears, teeth are so big. The wolf answers that they are big for seeing, hearing and eating the girl. The wolf devours the girl.

The result: Red Riding Hood is in the wolf's stomach.

5. The initial situation: Grandmother and Red Riding Hood are in the wolf's stomach. 
The act of the hero: A hunter kills the wolf. He cuts the wolf's stomach open and saves the grandmother and the girl.

The result: The grandmother and Red Riding Hood are alive and free.

The description of the elementary plots has been quite problematic. It is not clear how to intepret the mother's words in the first plot. She cautions the daughter to behave correctly when she tells her not to turn off the path. She may consider the dangers in the forest. Warning not to speak to anyone, however, sounds like a command. This act is characteristic of elementary plots in which the troubles sent upon heroes by antagonists are depicted. The characters who test the protagonist may be elder members of the community, animals (e.g., totemic animals - bear, wolf, horse's head, snake, serpent), or some mythical beings (witch, devil). The girl acts against the mother's command but suffers no consequences. She only tells the aim of her journey but does not reveal how to find her grandmother's house. The wolf finds it by himself.

The second and the third elementary plots are too laconic. It remains uncertain as to how the wolf manages to convince the grandmother that her granddaughter is behind the door. Also, no explanation is provided on why the wolf continues to pretend to be the grandmother when the wolf and Red Riding Hood are alone in the house. Finally, no explanation has been given on how the hunter comes upon the idea of cutting open the wolf's stomach.

The semantic interpretation of elementary plots is also complicated. The most enigmatic is the interaction of the girl and the wolf in the fourth elementary plot, which is the elementary plot in the text structure. If the wolf's aim is only to devour the girl, then why does he answer her questions? Also, the wolf could have devoured the girl already when they met in the forest.

These facts show that Ch. Perrault has substantially transformed the folk tale. On the basis of the tales recorded from oral tradition, an attempt will be made to reconstruct the tale heard by Ch. Perrault.

The tests to recognize the function of the things in the tester's world and to determine the status of the tester are known in Lithuanian magic tales and in the variants of other traditions. A girl goes to visit an elder relative (aunt, godmother) and sees unusual things. Sometimes she witnesses the relative having an abnormal feature (e.g., a godmother has a horse's head). The girl is ordered to tell what she has seen or what she is seeing. She describes the things according to their appearance or material. Sometimes she asks about the strange appearance of the tester. The tester reveals the function of things/ explains appearance and devours the girl (AT 334). The protagonist does not pass the trial and does not get the rights of the member of kin or community. It is equivalent of the right to live. 
Little Red Riding Hood pays attention to the wolf's external features (to the size of his eyes, ears, teeth) and the wolf tells her their functions, too. In only one Lithuanian manuscript variant the girl is left in the forest. She finds a house and enters. A tall old man comes into the house. The girl asks why he has so long legs, long hands, big eyes, and ears. The old man answers that so that his step would be long, that he could embrace two hundred people, he could see and hear to the distance of two hundred miles. At last the girl asks why he has such a big mouth. The old man devours the girl. ${ }^{2}$

This Lithuanian variant presents a typical testing of the protagonist without status. The protagonist does not pass the test because she does not guess the functions of the parts of the tester's body. This main elementary plot and analogous plots of 11 Lithuanian variants have been more or less influenced by the text of $\mathrm{Ch}$. Perrault, which the author has classified under type 3.2.0.10. The Hero Demonstrates that He Does not Recognize the Objects of the Other World. According to the type of the elementary plot, the variants of the tale could be classified under the structural-semantic type (the number and name coincide with the type-name of the main elementary plot) (Kerbelyte 2005: 245-248). I propose to classify Ch. Perrault's text under this type.

In Italian variants described by Uther and in Chinese variants an ogre/ witch/tigress pretends to be a girl's/children's mother or grandmother. The aim of these antagonists is to enter the house and swallow the girl or eat the children one by one. The girl/children notice(s) the features that are not similar to her/their mother's or grandmother's features. In Chinese variants the children ask why the grandmother has such a long tail. The tigress answers that it is not a tail but a long rope. The children ask why the grandmother's body is so hairy. The tigress answers that she is wearing a fur coat inside out (Baolin 1996: 67-71).

So the antagonist does not explain the functions of the parts of his body but tries to explain why his appearance is different from appearance of the protagonist's relative. The protagonist believes the explanation and opens the door or lets the dangerous antagonist into the house. This elementary plot could be classified under the type 1.2.1.6. The Hero Comes Close to the Dangerous Antipode. The main elementary plot of the text of Ch. Perrault (the fourth one in the above description) is thus interpreted by scholars and possibly by the seventeenth-century author in this way.

When the protagonist of the elementary plots of magic tales does not pass the tests the antagonists prepare for them, they get punished, even perish and lose their life. One exception to this rule is the variants of the international tale Rescue by the Sister (AT 311). The third sister passes the test and revives 
her murdered sisters. Another exception is some variants of the tale The Three Golden Children (AT 707). The brothers do not pass the test (as they look back while climbing up the hill) and are turned into rocks. After their sister passes the same test (as she does not look back while climbing up the hill), the brothers and the other people usually return to life "automatically", without any additional help from their sister. Sometimes the sister washes the rocks with the water of life.

It has been mentioned above that the hunter's actions are not motivated in the text of Ch. Perrault. The elementary plot of the same type is used logically when a wolf looks for meat and devours kids or an old man's animals or members of his family. The she-goat or the old man knows what has happened and cuts open the wolf's stomach (AT 123, 163).

The above-said enables to propose the reconstruction of the structure of the folk tale heard by $\mathrm{Ch}$. Perrault. It may have consisted of two elementary plots. Two tests or trials of the same hero may be related in them. When the hero does not pass the first trial he is not punished at once. This rule of connecting two/three negative elementary plots about the trials of the same protagonists in folktales may help to understand why the wolf does not devour the girl for not keeping silence during her journey. So the structure of the supposed text may be the sum of two negative elementary plots. Either of them may have existed independently, but the second element is more important in the junction. The description of the text's semantic structure (interpretations of elementary plots and ascribing them to the types as well as the type of connection) is as follows:

\begin{tabular}{|c|c|c|}
\hline $\begin{array}{l}\text { The girl does not keep silence } \\
\text { during her journey to the tester. } \\
\text { 3.2.0.6. The Hero does not } \\
\text { Endure the Difficult } \\
\text { Conditions During the Set } \\
\text { Time. }\end{array}$ & $7 \rightarrow$ & $\begin{array}{l}\text { The girl does not recognize the } \\
\text { functions of the parts of the } \\
\text { tester's body. } \\
\text { 3.2.0.10. The Hero } \\
\text { Demonstrates that He Does } \\
\text { not Recognize the Objects. }\end{array}$ \\
\hline
\end{tabular}

The elementary plots of both types can be found in magic folk tales. The variants of the type 3.2.0.6. are used in complicated plots. Only one elementary plot of type 3.2.0.10. contains the majority of variants of the Lithuanian tale Household of the Witch (AT 334). The variants have unhappy outcomes. One Lithuanian variant of the same structural-semantic type I have described above. Transformed elementary plots of the type 3.2.0.10. (the punishment of the hero is missing) are the main elements in the tale The Bridge to the Other World (AT 471). 
If the conflict between the girl and the wolf is interpreted as two tests of the hero by the antipode, a specific detail of the tale written in the 17th century becomes clear. The red cap is not Ch. Perrault's invention, as some folklorists have claimed. The girls who have reached the marriage age and brides were marked by red colour. According to D. Zelenin, Russian mothers used to sew new coloured dresses for their daughters of this age even at the beginning of the 20th century (Zelenin 1994: 179-192). The girls referred to as "Red Roses" are mentioned in the rituals of the cycle of the year among different nations in Europe. A blossoming rose at Christmas is the symbol of a girl's maturity in Lithuanian and in Ukrainian folk songs (Kerbelyte 1996: 344-347).

It is no coincidence that the grandmother of the Little Red Riding Hood lives alone in the forest. In several folktales, girls are tested by senior members of kin and by totemic animals in the houses in the forest.

Now I will return to the problem why the tale of Ch. Perrault is not popular among Lithuanian storytellers. The structure of the text is different from that of traditional folk tales. Only people with mechanical ability to memorize can repeat the tale of $\mathrm{Ch}$. Perrault. The text is not clear for people who are accustomed to the logical structures of folk tales. This is probably the main reason for the small number of variants of Little Red Riding Hood in Lithuanian folklore.

Why Lithuanian performers have not improved the text? In fact they do have tried to do so. Three variants have an unhappy conclusion. Moreover, storytellers have attempted to motivate the freeing of the swallowed characters. For example, in one variant, three hunters kill the wolf. The hunters want to divide the wolf's corpse and cut its stomach open. But the tale written in the 17 th century was not substantially improved because the storytellers know it as a printed and, in a sense, a "canonical" text.

\section{Comments}

${ }^{1}$ I am grateful to prof. Satu Apo for this information.

${ }^{2}$ Manuscripts of Lithuanian Folklore of the Institute of Lithuanian Literature and Folklore (Vilnius). 


\section{References}

Baolin, Duan. 1996. "Grandma Wolf" and "Little Red Riding Hood”. Folk Narrative and World View. Vorträge des 10. Kongresses der Internationalen Gesellschaft für Volkserzählungsforschung (ISFNR) Innsbruck 1992. Hrsg. Leander Petzoldt. Teil 1. Frankfurt am Main - Berlin - Bern - New York - Paris - Wien: Peter Lang. p. 67-71.

Kerbelyte 2005 = Кербелите Б. Типы народных сказок: структурно-семантическая классификация литовских народных сказок. Часть 1. Москва: Российский государственный гуманитарный университет. С. 245-248.

Kerbelyte $1996=$ Кербелите Б. Древо жизни $(\mathrm{K}$ вопросу о реконструкции фольклорных образов). Секс и эротика в русской традиционной культуре. Составитель А.Л. Топорков. Москва: Ладомир. С. 344-347.

Perrault, Charles. 1923, Perro pasakos. Mokinių vertimas. Redagavo J.Balčikonis. Kaunas, 1923. 169 p.

Perrault, Charles. 1948, 1985, 1991, 1997, Raudonkepuraitė. Iliustravo K.PetrikaitèTulienè. Vilnius. $15 \mathrm{p}$.

Uther, H.-J. 2004. The Types of International Folktales. A Classification and Bibliography. Based on the System of Antti Aarne and Stith Thompson. Part 1. FF Communications No 284. Helsinki. p. 224.

Zelenin 1994 = Зеленин Д.К. Обрядовое празднество совершеннолетия девицы у русских. Зеленин. Избранные труды. Статьи по духовной культуре 1901-1913. Москва: Индрик. С. 179-192. 